\title{
Study on the Water Conservation Management Measures in
}

\author{
Thermal Power Plants
}

\author{
Mian Xing \\ Department of Mathematics \& Physics, North China Electric Power University, China \\ E-mail: hdxm01@126.com
}

\begin{abstract}
First, the water consumption actuality of the electric power industry of China is analyzed in this article, and the necessity of the water-saving transformation in thermal power plants is proposed. Second, the type of water consumption in thermal power plants is analyzed, and eight parts of water consumption in thermal power plants are summarized in the production of thermal power plants. Finally, aiming at the characters of thermal power plant in China, the measures of water conservation and the methods of technical reform of water conservation are proposed to reduce the water consumption in the thermal power plants of China and offer solutions for the energy conservation and emission reduction.
\end{abstract}

Keywords: Thermal power plant, Water conservation, Technical reform, Energy conservation and emission reduction

The generated electrical energy amount of the thermal power plants occupies above $70 \%$ of the total electrical energy in China, and the thermal power generation industry is one of largest industry which consumes waters in China, and the development of the water conservation will directly influence the production management and sustainable development of thermal power plants. As viewed from the water consumption of the thermal power industry from 2000 to 2005 , though with the increase of the total thermal power installed capacity and the generated electrical energy, the water consumption of the thermal power plants in China increased, but the repeated utilization rate of the industrial water is enhanced year by year, and the water consumption rate of unit generated electrical energy is reduced gradually.

According to incomplete statistics, the average water consumption rate of the large thermal power plant adopting the circulating cooling system in 1980s in China was 1.42-1.56 cubic meters/ (s. million KW), and the average water consumption rate of the large thermal power plant of 0.3 million KW or 0.6 million KW built in 1990s could achieved 0.915 cubic meters/ (s. million KW). And the comparison of the water consumptions in the thermal power industry and the total national water consumption from 2000 to 2005 is seen in Table 1.

There are deficient freshwater in the north of China, and the water consumption and water conservation argumentation of new project is the key part of the water conservation to reduce the total water consumption, reasonably use water and reduce the pollution discharge.

\section{Water Consumption Type of Thermal Power Plants}

The thermal power plant is the big user of industrial water, and the thermal power plant mainly includes the boiler, the steam turbine, the coal clinker and the cooling tower, and the water consumption of the thermal power plant mainly contain following aspects.

\subsection{Boiler feed-water}

The operation process of the thermal power units can be described as that, first the high-pressure pump push water into the boiler to heat as the high-temperature steam, and the steam enters into the steam turbine to produce energy, and in this process, the pressure and temperature gradually reduce, and the steam turns into water finally by the help of exterior force, and then the high-pressure pump pushes the water into the boiler to heat. In fact, it is a continually circular process of "water- steam- water". In this closed circular process, the steam and water will be lost to some extents, such as the boiler pollution discharge loss, the boiler ash-blowing loss, and the steam leaking loss.

\subsection{Circulating cooling water}

After the steam produces energy in the steam turbine, the pressure and temperature of steam will be reduced very low, but it still needs water or air to cool it to make it turn into water. Turning the steam to the water at same temperature needs to release much potential heats, which needs the heat-eliminating medium to take these potential heats away, and general thermal power plant uses the cooling water to turn the steam into water by the condenser, and each ton of steam needs about 50 tons water to cool. After this heat exchange is completed, the temperature of the cooling water will be 
enhanced about 15 centigrade degrees. To recycle the cooling water, the cooling tower needs to be built to reduce the temperature of the cooling water. When the cooling water is cooled in the cooling tower, small part of it will be turned into steam, and blew away by the north wind, which is the "white smog" from the cooling tower seen by people usually. The wind-blowing loss of the cooling tower is the largest one in the water consumption of the thermal power plant. From the cooling tower suited for the thermal power units of 0.3 million KW, 300 tons water would be blew away by the north wind in one hour. If there is large water surface such as the big lake near the power plant, it can be utilized to cool the steam, and here, the loss of cooling water will be very small.

\subsection{Water consumption for ash and residue removal}

It is a big user of the thermal power plant. The water removal of ash and residue is to rush the ash collected in the smog and the residue from the boiler to the ash yard, and this operation mode is very simple to the thermal power plant. But it is difficult to computer the water consumption in the practice, in fact, the ash yards in many thermal power plants are a big reservoir, and in history, they collapsed and flooded several villages.

The present large coal-fired units all equip with the dusting equipment, and the fly ash collected by the dusting equipment is good building materials, and some thermal power plants grind the fly ash with the clinker produced by the cement factory to obtain the cement of No. 400 . And mixing $15 \% \sim 18 \%$ of fly ash into the concrete could enhance the quality of the concrete, for example, when building the big dam, the concrete is regulated to be mixed by certain proportional fly ash, which can increase the fluidity of the concrete and the anaphase strength, and save the using of cement. When the fly ash meets water, the activity will disappear, and the recycle value will lose, so to rush the fly ash by water not only wastes water but also is pity. The dry fly ash removal should be adopted, and this mode compresses the fly ash collected by the dusting equipment into the ash tank by the compressed air first, and then transports it to other place or the ash yard.

\subsection{Cooling water for assistant equipments}

It means all cooling waters such as the oil cooling water, the hydrogen and water cooling water in the generator, the cooling water of various blowers and water pumps except for the cooling water of the condenser of the steam turbine, and these cooling water consumptions are not large, and the indirect air cooling method could be adopted, i.e. building a small air cooling tower, to make the cooling water of the assistant equipment to circle closely, which could consume little water.

\subsection{Water for desulfurization}

To protect the environment, most present coal fired power plants need to equip the desulfurization equipment, and many plants adopt the wet smog-air desulfurization technology, i.e. gushing the mixes of water and limestone powders into the smog and gas to remove the sulfur dioxides in the smog air. The desulfurization effect of this method is very good, and $99 \%$ sulfur could be removed, and part of water can be recycled. In addition, to save the water consumption of the thermal power plant, the dry desulfurization could be adopted to save water. For example, to grind the limestone and coal and gush the mixes into the furnace, and add the limestone ash at the region of about 800 centigrade degrees in the furnace, could remove $75 \%$ sulfur.

\subsection{Dusting water in coal yard}

Most coal yards in China are outdoor yards, and they need sprinkling waters to bury dusts continually. How to save water and solve this problem? In fact, one or two large capacity tower coal storage bunker can be constructed, and the coals could be sent to the bunker directly after they are exploited. In this way, water is not needed in the coal yard again.

\subsection{Living water in power plants}

In the large thermal power plants, there are less employees and workers now, so the living water will be reduced (employees still need to be educated for saving waters anywhere). The production waters in many power plants are recycled water and dry water of coal, and because the living water requires higher quality and less quantity, so it should be solved independently such as the urban water supply when the plant is near the city.

\section{Main Water-Saving Measures in China}

\subsection{Reforming the circulating cooling water treatment system}

\subsubsection{Reasonably enhancing the concentration rate}

The concentration rate is an important control parameter in the circulating cooling eater system management, and it can reduce the compensation quantity of the antisludging agent and the inhibiter in the system. But the high concentration rate would require higher-quality treatment of fresh water and circulating water, and accordingly increase the charge of water treatment. Generally, according to the water saving requirements and the water treatment technology, the optimal concentration rate should be in $4 \sim 5$. From the statistical data, the concentration rate of above $80 \%$ Chinese thermal power plants is lower than the optimal concentration rate. The enhancement of the concentration rate of the thermal 
power plant could significantly reduce the water consumption index, and the concrete measures include (1) adopting the antisludging and antisepsis agents with better effect, and the acidification or the lime acidification technology and the weak acid resin treatment technology, to enhance the circulating water concentration rate above 3, (2) adopting the circulating water classification concentration series makeup technology.

\subsubsection{Enhancing the efficiency of the cooling tower and reducing the consumption of circulating cooling water}

The water consumption of the thermal power plant mainly is the water consumption of the cooling tower (about $70 \%$ of the total water consumption of the thermal power plant), and it includes the evaporation loss, the wind-blowing loss and the pollution discharge loss. The quantity of the water loss in the cooling tower is mainly decided by the circulating water quantity. To enhance the efficiency of the cooling tower and reduce the water consumption of the circulating cooling water, following measures can be adopted. (1) Replacing the cement filling as the high-performance plastic filling, and replacing the porcelain-mouth-porcelain-dish spraying equipment as the plastic reflecting spraying equipment. (2) Strengthening the maintenance, and clearing the cooling tower periodically and repairing the damaged equipments, and replacing the damaged filling and spraying equipments, to ensure the efficient water drenching area and degree. (3) Installing the water collect to reduce the wind-blow loss. (4) Setting up the water-level gauge in the pool of the cooling tower to link the water-level signal with the weak acid treatment system, and correspondingly increasing or reducing the water level of the weak acid treatment system according to the water-level of the pool. (5) Setting up the water-level control threshold in the water-makeup pipe of the cooling tower to avoid the flooding of the circulating water.

\subsubsection{Using the air cooling units in the coal-rich and water-deficient regions}

The air cooling system is also called as the dry cooling system, and it utilize the radiator composed by the air cooling wings with high-efficiency radiating effect to transfer the heat to the air and make the steam turbine to exhaust stream for condensation. The air cooling system could be divided into the direct air cooling, and the indirect air cooling with mixed condenser, and the indirect air cooling with the surface condenser. The water consumption of the air cooling system is very small, and comparing with the wet cooling units with same capacity, its cooling system could save above $97 \%$ of water itself, and save above $70 \%$ of the whole factory, and the water saving rate of the $200 \mathrm{MW}$ units is about $65 \%$, and the water saving rate of the $300 \mathrm{MW}$ units is about $70 \%$, the water saving rate of the $600 \mathrm{MW}$ units is about $75 \%$, and the water saving rate of the individual unit could achieve $90 \%$. The air cooling system is fit for the power plant where the water is deficient seriously, and the price of the coal is very cheap. Though the air cooling units of the thermal power plant could make the water saving rate of the whole factory to achieve above $65 \%$, the cost of the dry cooling tower is 2 4 times of the general cooling tower, and the cooling efficiency is bad, and the pressure of the steam turbine is higher, and the efficiency of the power plant could be correspondingly reduced (about $5 \%$ ), and the coal consumption will increase $4 \% \sim 5 \%$, so the electrical generation cost will be increased, and when the temperature is higher in the summer, the operation power will be reduced. So it should consider various influencing factors to decide whether adopting this technology. In recent years, the dry/wet comprehensive cooling system is researched and developed, and the proportion of the dry part and the wet part are decided by the water supply and the climate of the place of the power plant.

\subsubsection{Using seawater once through cooling technology or the seawater desalting technology in coastal regions}

In the once through cooling water system, the cooling water only passes the heat exchange equipment once, and then will be discharged, but the temperature rise of the discharged water is very small, and various minerals and ion contents in the water hold the line. Because the once through cooling water system has no losses such as evaporation, wind-blowing and pollution discharge, so its water consumption is much less than the circulating cooling power plant with same capacity, and this system needs less investments and simple operation.

\subsection{Reforming the ash and residue removal system}

The ash and residue removal system in the thermal power plant is another largest user of the water than the wet cooling system. According to the statistics, the ash removing water consumption of the thermal power plant of China is 0.98 billion cubic meters, and except for the evaporation and the leaking loss of the ash yard, the annual ahs removal water discharge is about 0.34 billion cubit meters, and the penalty each year could achieve about 30 million Yuan. In addition, the water quality of the ash removal water is bad, and the treatment charge is higher, so it is hard to be recycled, and it will induce the second pollution of the ground water and the surface water, and the ash residue will lose its activity when it contacts with the water, and the content of the calcium oxide in the ash water is higher, and the water scale in the system is very obvious. Therefore, the recycle of ash removal water would not only save water but also protect the environment. (1) The technical core of reducing the ash-water rate and save the ash removal water is to reduce the ash-water ratio and enhance the concentration of the ash slurry, and the ash-residue system adopts the ash-residue respective-removal method, and the ash removal system adopts the high-concentration water-power ash removal method, and the ash-water ratio is in 1:1 1:4. (2) The dry ash and residue removal system adopts the dry ash and 
residue removal method without water, and both the fly ash and residue produced by this technology can be recycled.

\subsection{Establishing the wastewater recycle system}

\subsubsection{Comprehensive treatment and recycle of wastewater}

The thermal power plant is the big water user, and produce quite large industrial wastewater, so the recycle of the industrial wastewater from the thermal power plant could reduce the pollution of wastewater to the environment. The wastewater recycle mode includes the decentralized treatment and the centralized treatment, and the thermal power plant with the single unit of the capacity of $600 \mathrm{MW}$ should adopt the centralized treatment mode of wastewater. Because the centralized treatment mode has perfect establishments and good water quality, it has been gradually accepted by many power plants such as the Baogang Power Plant, the Waigaoqiao Power Plant, and the Sanhe Power Plant. Because the water quality of wastewater from the power plant is very complex, and various equipments and systems use different standards of water quality, so for different wastewaters, different treatment methods should be adopted.

\subsubsection{Using the urban recycled water as the circulating cooling water}

The water treatment charges taking different water sources as the circulating cooling water are different, and when the concentration rate of the system is 2.0 , the treatment charge using recycled water is 0.48 Yuan/ton, and the treatment charge using water supply is $0.54 \mathrm{Yuan} / \mathrm{ton}$, and when the concentration rate is 5.0 , the treatment charge using recycled water is 0.35 Yuan/ton, and the treatment charge using water supply is 0.65 Yuan/ton. It is obvious that it is better to use the recycled water as the circulating makeup water than the water supply.

\subsection{Perfecting the water management}

It is an important measure to strengthen the water management of the thermal power plant, which could help to save water and reduce the consumption for the thermal power plant.

(1) Equipping the flow meter of the water consumption. The measurement of various main water consumption systems in the plant should adopt the first-class (water entering into the plant) meter (measuring the instantaneous flux and the accumulated flux) which supervision rate could achieve 100\%. The measurement of various workshop water consumption systems in the plant should equip the second-class (production water) meter which supervision rate could achieve $95 \%$. And the measurement of the water equipments in the plant could equip the third-class (living water) meter which supervision rate could achieve $90 \%$.

(2) Periodically correcting the flow meters. The flux precision of the water flow meters should exceed $\pm 2.5 \%$, and the flux precision of the drainage should exceed $\pm 5.0 \%$.

(3) Periodically testing the water consumption balance of the whole plant, and making the water consumption balance chart of the whole plant, the water users flow and distribution chart to record users' water consumption, and make the water consumption standards according to the practical situation, and exam the water consumption periodically and punish those users exceeding the standards.

(4) According to the water consumption balance of the plant, different waters with different qualities should be used differently to make the water consumption of the plant more reasonable and minimal.

The application of representative water conservation technologies in domestic thermal power plants is seen in Figure 2.

\section{References}

Huang, Yuanding. (1986). Wastewater Disposal in Thermal Power Plants. Beijing: Hydraulic and Electric Power Press.

Li, Qing \& Gong, Weiping. (2006). Energy Conservation and Index Management Technology of Thermal Power Plants. Beijing: China Electric Power Press.

Liu, Ruyi \& Huang, Yukun. (1990). Water Using and Water Saving in Power Plants. Beijing: Hydraulic and Electric Power Press.

Liu, Zhenqiang. (2006). Important Water Conservation Measures in Power Plants. Electrical Equipment. No.7(9). P.100-101.

Niu, Dongxiao, Wang, Yongli \& Duan, Lidong. (2009). Research on SVM-based Power Plant Construction Project Impact Evaluation Systems. East China Electric Power, No. 37(1). P.59-63

Wang, Peizhang. (2005). Application of New Technique of Save on Water in Steam Electric Plant. Electric Power Survey \& Design, No.1. P.74-77.

Wang, Peizhang. (2004). Capacity of Water-saving and Zero-discharge of Waste Water in Large Air-cooling Power Plant with 600 MW Unit. Power Station Auxiliary Equipment, No. 88(1). P.23-26.

Yang, Dongfang. (1991). Probe into the Water Conservation in Thermal Power Plants. Thermal Power Generation. 


\section{No.2. P.40-52.}

Zhang, Guixiang, Dong, Jianguo \& Li, Zhimin. (2003). A New Water-saving and Pollution Control Procedure for Fossil Power Plant-staged Concentrating and Cascade Water Makeup Technology for Circulating Cooling Water. Heibei Electric Power. No.22(5). P.52-54.

Zhang, Hongjie. (2007). Discussion on Water-saving Scheme in Thermal Power Plant. North China Electric Power. No.10. P.39-42.

Table 1. Comparison of the water consumptions in the thermal power industry and the total national water consumption from 2000 to 2005 (0.1 Billion Cubic Meters)

\begin{tabular}{|c|c|c|c|c|}
\hline Year & $\begin{array}{c}\text { Total national water } \\
\text { consumption }\end{array}$ & $\begin{array}{c}\text { Total industrial water } \\
\text { consumption }\end{array}$ & $\begin{array}{c}\text { Water } \\
\text { consumption of } \\
\text { thermal power }\end{array}$ & $\begin{array}{c}\text { Water usage of } \\
\text { thermal power }\end{array}$ \\
\hline 2000 & 5,497 & 1,139 & 455 & 45 \\
\hline 2001 & 5,567 & 1,142 & 470 & 47 \\
\hline 2002 & 5,497 & 1,150 & 509 & 49 \\
\hline 2003 & 5,320 & 1,177 & 521 & 53 \\
\hline 2004 & 5,548 & 1,248 & 597 & 58 \\
\hline 2005 & 5,578 & 1,278 & 635 & 63 \\
\hline
\end{tabular}

Table 2. Introduction of representative water conservation technologies

\begin{tabular}{|c|c|c|c|c|c|c|}
\hline \multicolumn{7}{|c|}{ Application of representative water conservation technologies in domestic thermal power plants } \\
\hline Item & $\begin{array}{c}\text { Investment(te } \\
\mathrm{n} \text { thousands } \\
\text { Yuan } \\
*(\mathrm{~m} 3 / \mathrm{h})-1)\end{array}$ & Technology & Power plant & $\begin{array}{c}\text { Installed } \\
\text { capacity } \\
\text { /MW }\end{array}$ & Water conservation technology & $\begin{array}{c}\text { Water } \\
\text { conservati } \\
\text { on rate }\end{array}$ \\
\hline \multirow{3}{*}{$\mid \begin{array}{c}\text { Circulat } \\
\text { ing } \\
\text { water } \\
\text { treatme } \\
\text { nt }\end{array}$} & \multirow{3}{*}{4.26} & \multirow{2}{*}{ Air cooling } & $\begin{array}{l}\text { Datong Power } \\
\text { Company }\end{array}$ & $2 \times 200$ & $\begin{array}{l}\text { Mixed indirect air cooling } \\
\text { system }\end{array}$ & 65 \\
\hline & & & $\begin{array}{c}\text { Zhangshan Power } \\
\text { Company }\end{array}$ & $2 \times 300$ & $\begin{array}{l}\text { Mechanical draught direct air } \\
\text { cooling system }\end{array}$ & 75 \\
\hline & & \begin{tabular}{|c|} 
High \\
concentration \\
rates
\end{tabular} & Xibaipo Power Plant & $4 \times 300$ & $\begin{array}{l}\text { Subsection condensed series } \\
\text { using water treatment }\end{array}$ & 26 \\
\hline \multirow{3}{*}{\begin{tabular}{|c|} 
Ash \\
residue \\
disposal \\
system
\end{tabular}} & \multirow{3}{*}{3.65} & $\begin{array}{l}\text { Dry ash } \\
\text { residues }\end{array}$ & Sanhe Power Plant & $2 \times 350$ & $\begin{array}{l}\text { Cooling hot residues by air, and } \\
\text { removing ashes by air }\end{array}$ & 24 \\
\hline & & Air ash removal & $\begin{array}{c}\text { Taiyuan First } \\
\text { Thermal Power Plant }\end{array}$ & $2 \times 300$ & $\begin{array}{l}\text { Macawber air ash-removing } \\
\text { technology }\end{array}$ & 24 \\
\hline & & $\begin{array}{l}\text { Dry ash } \\
\text { repertory }\end{array}$ & Ezhou Power Plant & $2 \times 300$ & $\begin{array}{l}\text { Stacking dry ashes by ash } \\
\text { removal and belt conveyor }\end{array}$ & 24 \\
\hline \multirow{2}{*}{$\begin{array}{c}\text { Waster } \\
\text { water } \\
\text { recycle }\end{array}$} & \multirow{2}{*}{3.24} & $\begin{array}{c}\text { Utilizing urban } \\
\text { wastewater }\end{array}$ & $\begin{array}{l}\text { Beijing Thermal } \\
\text { Power }\end{array}$ & $712(4)$ & $\begin{array}{c}\text { Wastewater regenerated water as } \\
\text { the make-up water }\end{array}$ & 60 \\
\hline & & $\begin{array}{l}\text { Cycle water } \\
\text { zero discharge }\end{array}$ & Xibaipo Power Plant & $4 \times 300$ & Series using of cycle water & 26 \\
\hline
\end{tabular}

